\title{
Biomarkers of bone health appropriate for evaluating functional foods designed to reduce risk of osteoporosis
}

\author{
Connie M. Weaver ${ }^{1}$ and Michael Liebman ${ }^{2}$ \\ ${ }^{1}$ Department of Foods and Nutrition, Purdue University, West Lafayette, IN 47907-1264, USA \\ ${ }^{2}$ Department of Family and Consumer Sciences (Human Nutrition), University of Wyoming, Laramie, WY 82071-3354, USA
}

\begin{abstract}
Osteoporosis is a growing global problem. The health care costs and decreased productivity and quality of life are staggering. Much research is invested in life-style approaches to build peak bone mass during growth to prevent osteoporosis as well as to treat the disease in later life. Functional foods have enjoyed a niche in bone health. Foods fortified with $\mathrm{Ca}$ are most popular. Other bone nutrients such as vitamin $\mathrm{D}, \mathrm{Mg}$ and vitamin $\mathrm{K}$ are sometimes added. Future products are likely to include enhancers of $\mathrm{Ca}$ absorption such as inulin or whey proteins. Dietary factors that reduce urinary Ca loss (plant proteins) or suppress bone resorption (possibly phyto-oestrogens) are also gaining attention. Methodologies for evaluating the effectiveness of functional foods on bone health include measures of bone quality such as bone densitometry or measures of Ca metabolism, particularly absorption. Biochemical markers for bone turnover are less satisfactory for diet-related effects. Use of a rare isotope, ${ }^{41} \mathrm{Ca}$, and accelerator mass spectrometry offers a new approach for assessing the ability of functional foods to suppress bone resorption.
\end{abstract}

Osteoporosis: Bone health: Food fortification: Biochemical biomarkers: Calcium

\section{Introduction}

Biomarkers to evaluate the effectiveness of functional foods for bone health are quite advanced compared with many other diseases. Yet, simple, inexpensive and rapid methods for evaluating large numbers of people are still lacking. The appropriate choice of an outcome measure depends on the mechanism of action of the functional food and the targeted population. Functional foods designed to prevent osteoporosis may work by providing a key nutrient important to bone development and maintenance, by enhancing $\mathrm{Ca}$ absorption or retention, by building peak bone mass or by suppressing bone turnover and, therefore, bone loss. Because functional foods for bone health are largely targeted towards increasing $\mathrm{Ca}$ intake or utilization of $\mathrm{Ca}$, the focus of this review will be on strategies to improve $\mathrm{Ca}$ nutrition and methods to evaluate their effectiveness.

\section{Importance of adequate dietary calcium}

There is a renewed interest in the importance of adequate $\mathrm{Ca}$ intake, because of a greater appreciation of its role in health and disease prevention. The role of $\mathrm{Ca}$ in bone health is best understood as the primary cation in bone (Bryant et al. 1999). Requirements of $\mathrm{Ca}$ are based on intakes adequate for bone accretion and maintenance. There are many other health reasons to achieve adequate $\mathrm{Ca}$ intake. The role of $\mathrm{Ca}$ and dairy product consumption in vascular tone and blood pressure control was reviewed recently (McCarron \& Reusser, 1999). Observational studies suggest adequate $\mathrm{Ca}$ decreases risk of kidney stones, probably by decreasing urinary oxalate level (Heller, 1999). Increasing $\mathrm{Ca}$ and dairy food intakes appear to reduce risk of colon cancer, probably through lowering faecal bile acid and fatty acid concentrations, which lowers cytotoxity (Holt, 1999). The reversal of dietary fat-induced hyperplasia and hyperproliferation in mammary and colonic tissues in mice when $\mathrm{Ca}$ and vitamin $\mathrm{D}$ were supplemented led to the recent suggestion that $\mathrm{Ca}$ is also important in preventing breast cancer (Lipkin \& Newmark, 1999). A multi-centre trial showed that Ca supplementation significantly $(P<0.05)$ decreased premenstrual symptoms relative to those observed in a placebo-controlled group (Thys-Jacobs et al. 1998). More recently, adequate $\mathrm{Ca}$ intake has been associated with maintenance of body fat and body weight (Lin et al. 2000; Zemel et al. 2000).

$\mathrm{Ca}$ intakes for most groups over the age of 11 years fall short of the recommended intakes in North America (Food and Nutrition Board, 1997) and many other parts of the world. $\mathrm{Ca}$ absorption and retention are inefficient. $\mathrm{Ca}$ 
absorption in adults averages only $30 \%$ (Heaney et al. 1988) and losses through endogenous secretions approximate $120 \mathrm{mg} / \mathrm{d}$ regardless of intake (Wastney et al. 1996). Early man is thought to have consumed liberal amounts of $\mathrm{Ca}$ compared with the intake of modern man (Eaton \& Konner, 1985). Because osteoporosis and the other diseases described above typically occur post reproduction, there is little evolutionary pressure to adapt to the current low intake of $\mathrm{Ca}$. Increasing $\mathrm{Ca}$ intake is a prudent solution to the $\mathrm{Ca}$ deficit, but improving absorption and retention could also improve $\mathrm{Ca}$ nutriture.

\section{Absorption: mechanisms and methodology}

$\mathrm{Ca}$ bioavailability is frequently equated to $\mathrm{Ca}$ absorption. Absorption is the first barrier to achieving $\mathrm{Ca}$ homeostasis. Dietary factors that affect excretion or bone resorption, i.e. net retention, will be discussed in later sections. $\mathrm{Ca}$ is absorbed both by active, transcellular and by passive, paracellular processes (Fig. 1). Active absorption dominates at low $\mathrm{Ca}$ intake, but owing to its saturable nature and subsequent down-regulation at adequate intake, this pathway becomes less important with increasing $\mathrm{Ca}$ intake. $\mathrm{Ca}$ absorption efficiency is inversely related to $\mathrm{Ca}$ load over a wide range of intake, although the absolute quantity of $\mathrm{Ca}$ absorbed increases with increased load (Heaney et al. 1990b).

Methods to assess $\mathrm{Ca}$ bioavailability include $\mathrm{Ca}$ balance, determination of bone (or whole-body) $\mathrm{Ca}$ retention, and the use of intestinal loops, Caco-2 cells and isotopic tracers. These span studies in man, animal models and in vitro techniques. $\mathrm{Ca}$ balance studies are expensive and can lead to erroneous results unless sufficient attention is paid to ensuring the completeness of food intake and urine and faecal collections. An additional challenge is the demarcation of faeces to time intervals that can be

Lumen

Blood

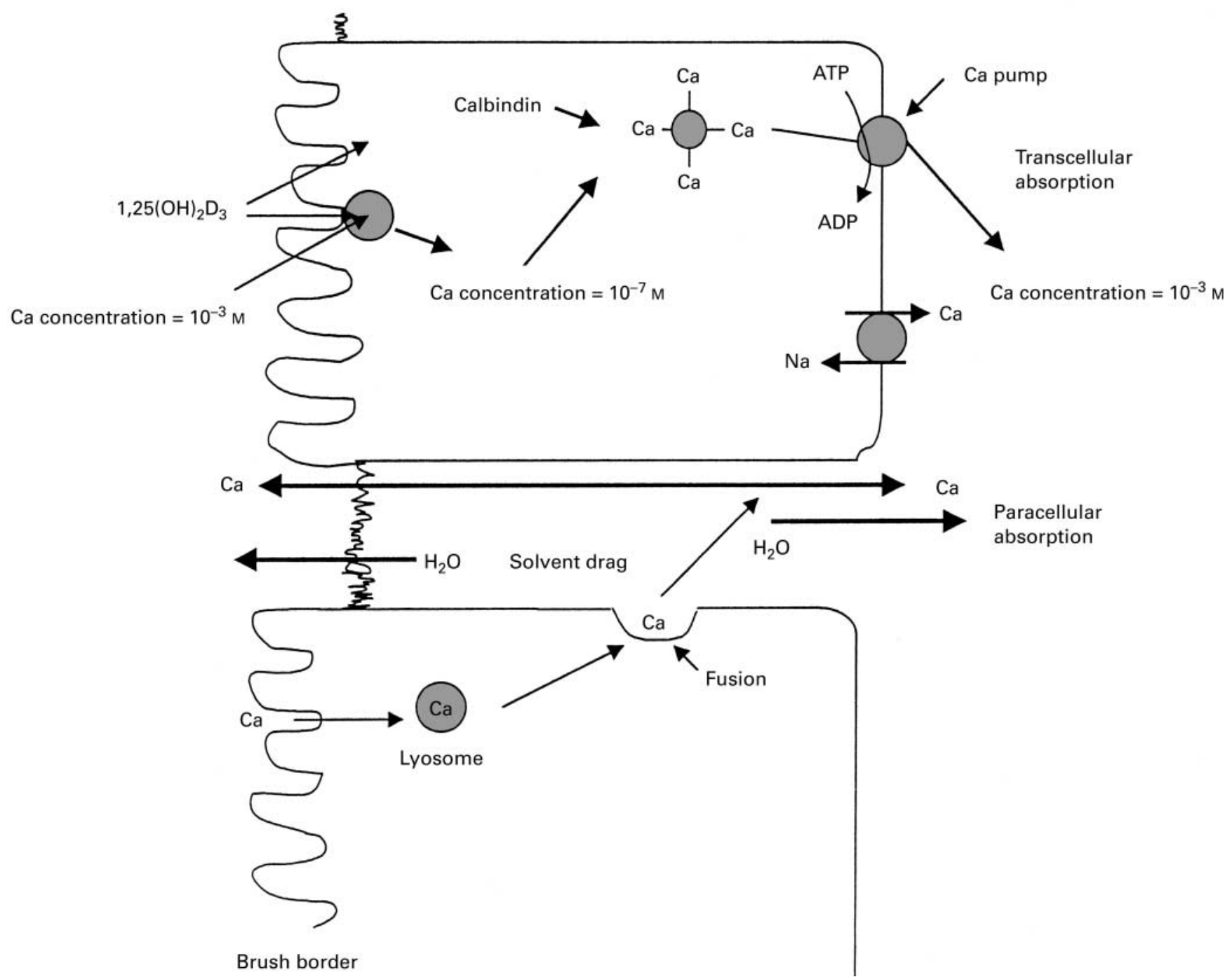

Fig. 1. Calcium absorption from intestinal lumen through intestinal epithelium to blood. Calcium can be absorbed (1) transcellularly, by a process mediated by $1,25(\mathrm{OH})_{2}$ vitamin $\mathrm{D}$-induced carrier, calbindin $\mathrm{D}_{9}$, or by endocytosis of acidic lysosomes; or (2) paracellularly, a passive process. 
related to specific $\mathrm{Ca}$ intake; validity is improved markedly in this regard when faecal results are corrected for recovery of a quantitative faecal marker (Hargreaves \& Rose, 1965). Appropriate uses of balance studies include comparisons of the bioavailability of different sources of $\mathrm{Ca}$ and to help quantify complex nutrient interactions which affect bioavailability (Mertz, 1987). Ca balance studies have contributed to the body of literature that suggests that both oxalate (Kelsay \& Prather, 1983; Liebman \& Doane, 1989) and phytate (Morris \& Ellis, 1985; Liebman \& Landis, 1989) are important inhibitors of $\mathrm{Ca}$ absorption. Balance studies can determine net $\mathrm{Ca}$ absorption, but not true absorption.

In animal models, the bone (femur) uptake method compares femur accumulation of an oral dose of an isotope tracer with a dose injected intraperitoneally. This method is based on the assumption that the intraperitoneal injection behaves as an oral dose with $100 \%$ absorption. With use of the whole-body counting technique, absorption of $\mathrm{Ca}$ from an oral dose of an isotopic tracer is based on extrapolating the linear portion of a retention curve to time zero (Koo et al. 1993). Koo et al. (1993) demonstrated that assessments of radiotracer activity of $\mathrm{Ca}$ in femur or whole body are equally accurate for comparing bioavailability of $\mathrm{Ca}$ among sources. Not having to collect excreta or multiple blood samples is a clear advantage of these methods.

Ca absorption can also be assessed with use of the in situ loop and everted sac methods. Studies based on these methods clearly established the existence of two $\mathrm{Ca}$ absorptive processes, a vitamin D-dependent, saturable, transcellular pathway that predominates in the duodenum and a non-saturable, paracellular pathway that occurs throughout the entire length of the small intestine (Pansu et al. 1983; Bronner et al. 1986). However, they are insensitive to the important factor of exposure time of the chyme to the mucosa.

Pinto et al. (1983) demonstrated that cultured Caco-2 cells, a human colon adenocarcinoma cell line, exhibit structural and functional differentiation patterns characteristic of mature enterocytes. Yee (1997) reported a strong correlation between in vitro permeability across Caco-2 cells and in vivo (small intestinal) absorption for a variety of compounds. It has also been confirmed recently that vitamin D-mediated Ca transport in these cells is a specific, transcellular process that requires transcriptional events normally mediated through the vitamin D receptor (Fleet \& Wood, 1999). However, in culture, these cells form a membrane with tight junctions that interfere with measurement of transport.

Some have tried to use rise in urinary $\mathrm{Ca}$ to determine relative bioavailability, but this is a weak approach especially for $\mathrm{Ca}$ loads less than $500 \mathrm{mg}$. For example, variability in rise in urinary $\mathrm{Ca}$ was $77-99 \%$ compared with 38-60\% for serum Ca following ingestion of three $\mathrm{Ca}$ salts (Heaney et al. 2001). Increments in serum Ca are also less sensitive than following the fate of isotopic tracers of $\mathrm{Ca}$. Isotopic tracers have been used to label dietary sources of $\mathrm{Ca}$ for the measurement of $\mathrm{Ca}$ bioavailability in both animal models and man. Ca has two useful radioisotopes $\left({ }^{45} \mathrm{Ca}\right.$ and $\left.{ }^{47} \mathrm{Ca}\right)$, several useful stable isotopes $\left({ }^{42} \mathrm{Ca},{ }^{43} \mathrm{Ca},{ }^{44} \mathrm{Ca},{ }^{46} \mathrm{Ca}\right.$ and $\left.{ }^{48} \mathrm{Ca}\right)$, as well as one long-lived radioisotope $\left({ }^{41} \mathrm{Ca}\right)$. Tracers can be followed by appearance in plasma, excretion or by whole-body retention in the case of ${ }^{47} \mathrm{Ca}$. Use of tracers for determining $\mathrm{Ca}$ absorption gives true absorption, in contrast to net absorption determined by balance. Intrinsic labelling of a broad array of hydroponically grown plants, milk made into a variety of dairy products and salts has enabled determination of $\mathrm{Ca}$ absorption in man from most Ca-rich foodstuffs in the Western diet (Weaver et al. 1999). Isotopic tracers can also be used to determine transfer rates, sites of absorption and pathway of absorption. When absorption is plotted $v$. various Ca loads, a curvilinear relationship suggests active transport and a linear relationship suggests paracellular absorption (see Fig. 2).

\section{Modifying calcium absorption}

In a recent review, Bronner \& Pansu (1999) stated: 'It is obvious that calcium must be ionized and in solution to be absorbed'. Typically, Ca must be dissociated from its ligands in a foodstuff prior to absorption. However, there is recent evidence that $\mathrm{Ca}$ from a small-molecular-weight compound did not require dissociation prior to absorption (Hanes et al. 1999a,b). This was apparent because Ca and oxalic acid have very different serum appearance profiles, yet doubly labelled ${ }^{45} \mathrm{Ca}-\left[{ }^{14} \mathrm{C}\right]$ oxalate showed parallel serum profiles of the two labels until the unabsorbed salt reached the colon, where bacterial hydrolysis presumably occurs. It is tempting to conclude that absorption of the salt occurred paracellularly, but calcium oxalate could conceivably transverse the epithelial membrane because it is apolar. The implications of this finding might be greatest for individuals with defective active $\mathrm{Ca}$ absorption capacity.

Solubilization is a reasonable assumption prior to $\mathrm{Ca}$ absorption, at least at the absorptive surfaces. Yet, in vitro solubility of $\mathrm{Ca}$ salts at neutral $\mathrm{pH}$ over a wide range had little impact on $\mathrm{Ca}$ absorption (Heaney et al. $1990 a$ ). For example, $\mathrm{Ca}$ absorption from $\mathrm{CaCO}_{3}$ with a solubility of $0.14 \mathrm{mmol} / \mathrm{l}$ is as good as from tricalcium phosphate, which is nearly an order of magnitude more soluble at $0.97 \mathrm{mmol} / \mathrm{l}$. Only salts that are at the extreme

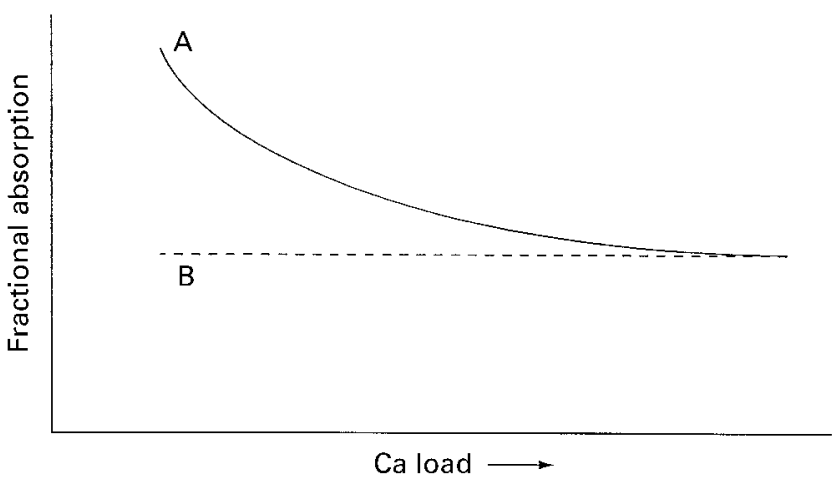

Fig. 2. Illustration of (A) saturable and (B) non-saturable components of calcium kinetics curves. At large calcium loads, active transport approaches a small value. The linear portion of the curve reflects constant and paracellular absorption. 
ends of solubility have appreciably different $\mathrm{Ca}$ absorption efficiencies.

Other factors that influence $\mathrm{Ca}$ bioavailability include the presence of inhibitors and enhancers in the diet. Functional foods for bone health may decrease the content of inhibitors and increase the content of enhancers. The most potent inhibitor of $\mathrm{Ca}$ absorption is oxalate (Heaney \& Weaver, 1989). Fibre has been labelled as an inhibitor of $\mathrm{Ca}$ absorption since the early balance studies of McCance \& Widdowson (1942). However, research with purified fibres has suggested that fibre does not influence $\mathrm{Ca}$ absorption appreciably (Heaney \& Weaver, 1995). This is supported by the finding that $\mathrm{Ca}$ absorption efficiency from fibre-rich brassica vegetables is higher than from other foodstuffs (Weaver et al. 1999). The presence of an enhancer of Ca absorption in brassica vegetables is suspected, but not yet identified. In contrast to the lack of fibre effect, phytates associated with cereal and legume fibres can decrease $\mathrm{Ca}$ absorption (Heaney et al. 1991; Weaver et al. 1991). The capacity of phytate-rich extruded wheat bran cereal to bind $\mathrm{Ca}$ is linear over a wide range of $\mathrm{Ca}$ intake (Weaver et al. 1996).

Few $\mathrm{Ca}$ absorption enhancers have been identified. Most research has concentrated on searching for highly absorbable $\mathrm{Ca}$ salts. Only a few have been identified, including calcium citrate malate with a solubility of $80 \mathrm{mmol} / \mathrm{l}$ (Miller et al. 1988), calcium gluconate glycerophosphate (Schanler \& Abrams, 1995) and calcium ascorbate (Tsugawa et al. 1999). Additionally, a few Ca absorption enhancers have been identified. Consumption of $15 \mathrm{~g}$ oligofructose/d increased stable isotopic tracer $\mathrm{Ca}$ absorption from $47.8 \%$ during a placebo period to $60.1 \%$ (van den Heuvel et al. 1999). Feeding of $40 \mathrm{~g}$ inulin/d increased apparent $\mathrm{Ca}$ absorption in adults participating in a balance study from 21.3 to $33.7 \%$ (Coudray et al. 1997). Certain amino acids, notably lysine, and casein phosphopeptides, digestive products from milk proteins, have $\mathrm{Ca}$ absorption-enhancing effects under some conditions such as in women with low absorption efficiency (Heaney et al. 1994). Yet another type of Ca absorption enhancer is the hydrolysis product of phytic acid, 1,2,3,6-inositol tetrakisphosphate, which improved ${ }^{45} \mathrm{Ca}$ absorption efficiency from 26.2 to $30.7 \%$ in rats using calcium ascorbate as the $\mathrm{Ca}$ source (Shen et al. 1998).

Enhancement of $\mathrm{Ca}$ absorption has typically been attributed to the formation of soluble complexes with $\mathrm{Ca}$ which prevent precipitation by $\mathrm{P}$ in the gut. Other mechanisms of enhancing $\mathrm{Ca}$ absorption deserve to be explored. Increasing paracellular absorption is promising because it is not limited by becoming saturated, it is vitamin Dindependent, and it occurs throughout the length of the intestine in contrast to active absorption which is dominant in the duodenum. If the intercellular junction spaces illustrated in Fig. 1 can be widened, more $\mathrm{Ca}$ could be absorbed. Or, if solvent drag could be increased, even though water would flow bidirectionally, given the large volume of blood that would serve to dilute ions extruded from the basolateral membrane, ions would have a net movement from lumen to blood. Ideal compounds would be those that could be incorporated into $\mathrm{Ca}$-containing food to enhance absorption of $\mathrm{Ca}$ but would have only a transient effect, so that transfer of undesirable organisms and ions would be minimized. Pappenheimer \& Reiss (1987) provided evidence that glucose and amino acids in the lumen of the small intestine increase solvent drag through paracellular channels by fuelling the contraction of epithelial cytoskeletal elements, thereby opening tight junctions to allow mass transport of nutrients.

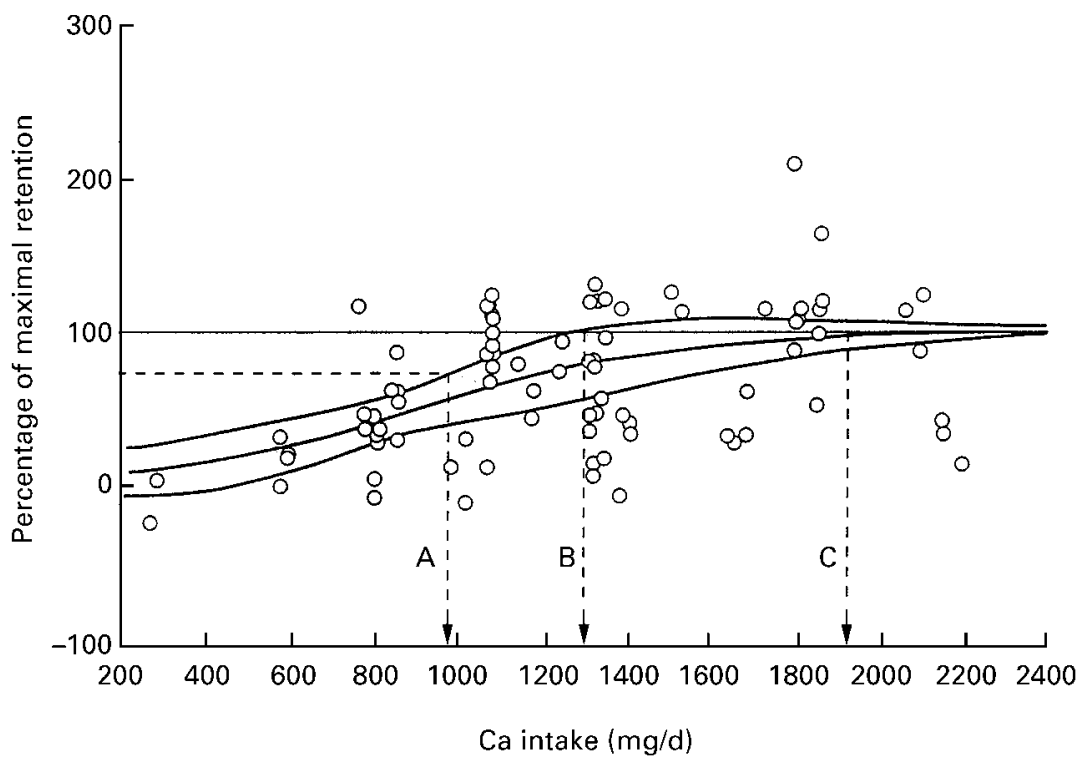

Fig. 3. Relationship between calcium retention and calcium intake in adolescent Caucasian girls (mean and $95 \%$ confidence intervals). Calcium intakes required to achieve: (A) $70 \%$ of maximal retention at the lower edge of the confidence interval; (B) $100 \%$ of maximal retention at the upper edge of the confidence interval; and (C) $100 \%$ of maximal retention at the mean. 


\section{Modifying calcium retention}

Dietary factors that alter $\mathrm{Ca}$ absorption or $\mathrm{Ca}$ excretion can modify $\mathrm{Ca}$ retention. Nutrients with the greatest impact on $\mathrm{Ca}$ loss include salt and protein, both of which increase urinary $\mathrm{Ca}$ output. Ironically, $\mathrm{Ca}$ intake influences urinary $\mathrm{Ca}$ output only modestly; only $6 \%$ of the variance in urinary $\mathrm{Ca}$ in adolescents was explained by $\mathrm{Ca}$ intake (Jackman et al. 1997). Data on the effect of dietary variables on $\mathrm{Ca}$ retention are collected largely in adults. We know little of these relationships across the life span or of the impact of race or other genetic determinants.

Perhaps a more useful way of determining the impact of dietary variables on $\mathrm{Ca}$ retention is to determine how $\mathrm{Ca}$ requirements might be affected by various dietary patterns and for different populations. The relationship between $\mathrm{Ca}$ retention and $\mathrm{Ca}$ intake has been examined for various populations (Matkovic \& Heaney, 1992). For all populations, there is a linear relationship up to a certain intake after which there is a levelling off of the curve so that further increases in $\mathrm{Ca}$ intake produce little further gain in retention. The intake at which this plateau occurs is a reference value for setting requirements to maximize development of peak bone mass during growth and minimize bone loss during ageing. There is no consensus on whether requirements should be set at $100 \%$ of maximum retention or at some lower target. Nor is it clear how to determine intake for a given percentage retention taking into account variability. Figure 3 shows the mean and $95 \%$ confidence interval of the relationship between $\mathrm{Ca}$ retention and $\mathrm{Ca}$ intake in adolescent girls using the data of Jackman et al. (1997). Should the Ca requirement be set at extrapolated value A ( $70 \%$ of maximal retention taken at the lower limit of the $95 \%$ confidence interval), value B (100\% maximal retention taken at the lower limit of the $95 \%$ confidence interval), value $\mathrm{C}$ (the mean
$100 \%$ maximal retention), or some other value? The first value is arbitrary. The second value is dependent on sample size and inter-subject variability, which influences the confidence interval. The third value may be impractically high.

Regardless of how the relationship of $\mathrm{Ca}$ retention to $\mathrm{Ca}$ intake is used to set requirements, knowing the relationship is the first step. Understanding how the relationship can be influenced by dietary life-style and genetic factors is the next area of needed research. Theoretically, dietary patterns which include high bioavailable $\mathrm{Ca}$, low salt and low protein can shift the curve to the left (Fig. 4), whereas diets characterized by low Ca bioavailability, high salt and high protein can shift the curve to the right (Fig. 5). Similarly, the curve might be shifted according to race, ethnic group, physical activity level, smoking and other factors.

\section{Modifying bone turnover}

Functional foods that promote health by modifying bone turnover may work by enhancing bone formation or suppressing bone resorption. Increasing $\mathrm{Ca}$ intake during adolescence results in increased $\mathrm{Ca}$ absorption, which suppresses bone resorption by the equivalent amount (Wastney et al. 2000). Phyto-oestrogens may provide some protection against bone resorption similar to oestrogen, although this is not yet well documented (Weaver et al. 2001). Suppression of bone resorption can lead to increased $\mathrm{Ca}$ retention.

Use of $\mathrm{Ca}$ isotopic tracers and kinetic analysis allows quantification of bone formation and bone resorption in units of $\mathrm{Ca}$ such as $\mathrm{mg}$ of $\mathrm{Ca}$ per day. Use of just one dose of the rare isotope, ${ }^{41} \mathrm{Ca}$, and accelerator mass spectrometry opens the possibility of determining types of diet changes that might suppress bone resorption in

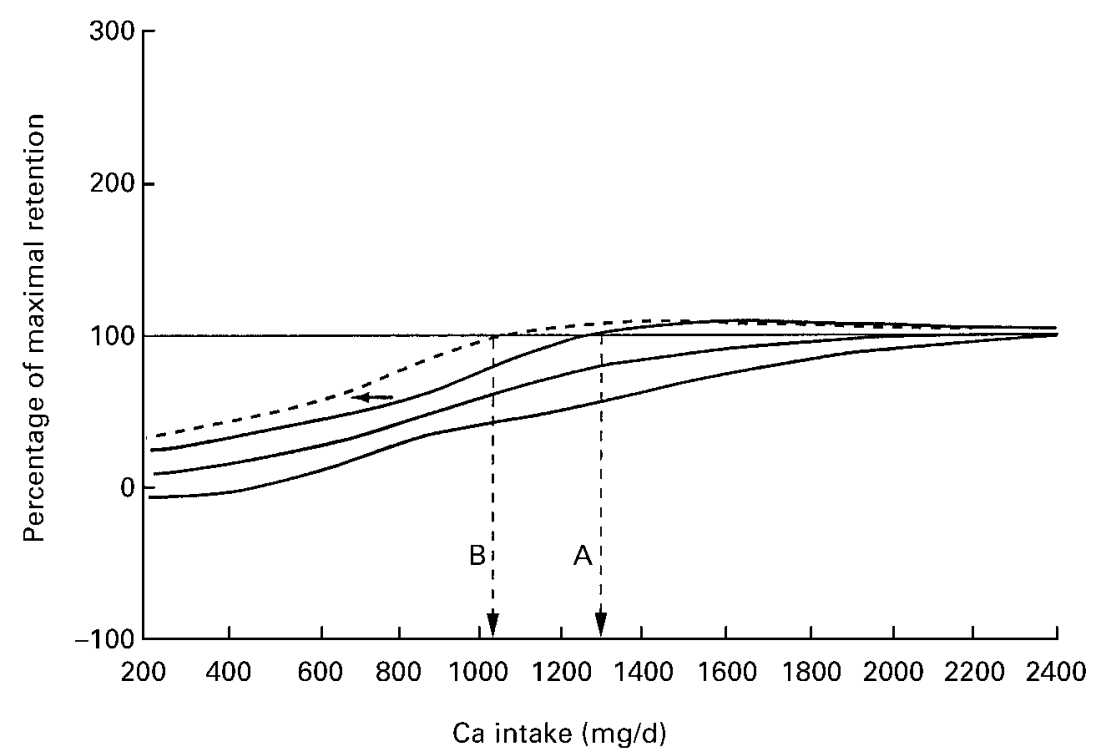

Fig. 4. The curve of calcium retention $v$. calcium intake shifts to the left with high bioavailability, low-salt and low-protein diets. $A$ is the original intake to achieve maximal retention at the upper edge of the confidence interval and $B$ is the new intake when the curve is shifted to the left. 


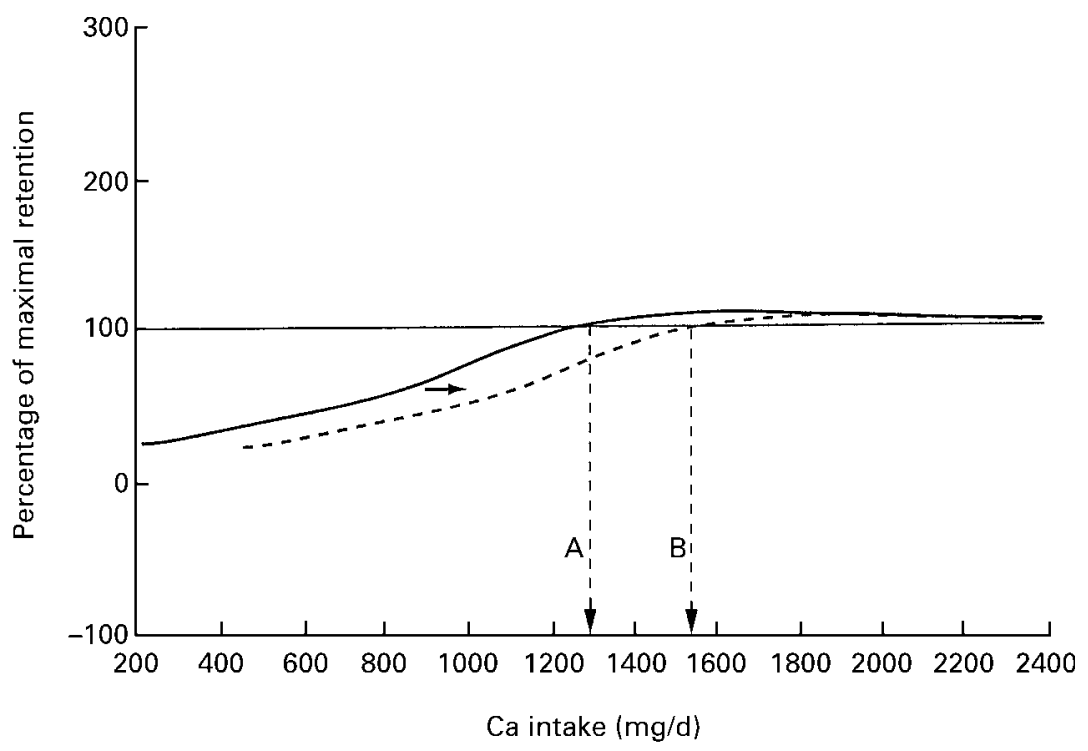

Fig. 5. The curve of calcium retention $v$. calcium intake shifts to the right with low bioavailability, high-salt and high-protein diets. $\mathrm{A}$ is the original intake to achieve maximal retention and $B$ is the new intake when the curve is shifted to the right.

individuals followed longitudinally. Approximately two months after dosing, the appearance of ${ }^{41} \mathrm{Ca}$ in the urine directly reflects bone resorption. The sensitivity of accelerator mass spectrometry allows the tracer to be followed for years, thereby allowing assessments of changes in diet or other life-style factors.

Biochemical markers of bone turnover have also been used to determine qualitative changes in bone turnover (Weaver, 1998). Some common biochemical markers of bone formation include serum osteocalcin and bone alkaline phosphatase. Biochemical markers of bone resorption are typically urinary crosslinks of collagen. These assays are not in units of bone or $\mathrm{Ca}$ and results are highly variable. Larger sample sizes are required to find significant treatment effects. Frequently, the subtle effects of diet cannot be detected.

\section{Bone mineral density}

Bone mineral density is a strong biomarker for fracture. To evaluate the effectiveness of functional foods using this method, the intervention period needs to be much longer than for evaluating parameters of Ca metabolism. Ideally, interventions would have the duration of three to four sigmas. Each sigma, the period for a complete cycle of bone resorption and formation, is about four months in man. Trials of short duration fail to show the long-term impact on bone health. One study showed the benefit of one year of Ca-fortified foods on bone measures in growing children (Bonjour et al. 1997).

\section{Conclusions}

Increasing the $\mathrm{Ca}$ intake of the general population is the most effective strategy for using functional foods for bone health. Despite education efforts and the increased availability of an array of Ca-fortified foods and supplements, intake of $\mathrm{Ca}$ remains inadequate. The role of $\mathrm{Ca}$ bioavailability and the ability to maximize absorption and retention are less important under conditions of adequate intake. A variety of methods are available to evaluate the effectiveness of functional foods for bone health. Their effect on $\mathrm{Ca}$ absorption can be determined by in vitro techniques, use of animal models or in man. Use of $\mathrm{Ca}$ isotopic tracers offers a specific way to determine the point of $\mathrm{Ca}$ metabolism affected. Understanding mechanisms of $\mathrm{Ca}$ absorption and how to increase absorption and retention efficiency are also important.

In the next decade, we will understand better the dietary and life-style factors that influence $\mathrm{Ca}$ absorption by both transcellular and paracellular routes. We will understand better how dietary factors influence the relationship between $\mathrm{Ca}$ retention and $\mathrm{Ca}$ intake. We will understand better the genetic factors that influence $\mathrm{Ca}$ absorption and retention. That $\mathrm{Ca}$ retention has a large genetic component was demonstrated by the greater response to $\mathrm{Ca}$ of three generations of women who were from osteoporotic families compared with women from healthy families (O’Brien et al. 1998). A beginning in identifying a specific gene that may influence $\mathrm{Ca}$ absorption is the significant association of vitamin D receptor gene Fok 1 polymorphism with $\mathrm{Ca}$ absorption and bone mineral density in children aged 7.5-12 years (Ames et al. 1999). Perhaps one day we will be able to tailor the food supply for identifiably vulnerable segments of the population.

\section{Acknowledgements}

This work was support by grants PHS AR 40553 and HD 36609. 


\section{References}

Ames SK, Ellis KJ, Gunn SK, Copeland K \& Abrams SA (1999) Vitamin D receptor gene Fok 1 polymorphism predicts calcium absorption and bone mineral density in children. Journal of Bone and Mineral Research 14, 740-746.

Bonjour JP, Carrie AL, Ferriri S, Clavien H, Slosman D, Thientz G \& Rizzoli R (1997) Calcium-enriched foods and bone mass growth in prepubertal girls - a randomized, double-blind, placebo-controlled trial. Journal of Clinical Investigation 99, 1287-1298.

Bronner F \& Pansu D (1999) Nutritional aspects of calcium absorption. Journal of Nutrition 129, 9-12.

Bronner F, Pansu D \& Stein WD (1986) An analysis of intestinal calcium transport across the rat intestine. American Journal of Physiology 250, G561-G569.

Bryant RJ, Cadogan J \& Weaver CM (1999) The new Dietary Reference Intakes for calcium: implications for osteoporosis. Journal of the American College of Nutrition 18, 406S-412S.

Coudray C, Bellanger J, Castiglia-Delavaud C, Remesy C, Vermorel M \& Rayssignuier Y (1997) Effect of soluble or partly soluble dietary fibres supplementation on absorption and balance of calcium, magnesium, iron and zinc in healthy young men. European Journal of Clinical Nutrition 51, $375-380$.

Eaton SB \& Konner M (1985) Paleolithic nutrition: a consideration of its nature and current implications. New England Journal of Medicine 312, 283-289.

Fleet JC \& Wood RJ (1999) Specific $1,25(\mathrm{OH})_{2} \mathrm{D}_{3}$-mediated regulation of transcellular calcium transport in Caco-2 cells. American Journal of Physiology 276, G958-G964.

Food and Nutrition Board (1997) Dietary Reference Intakes for Calcium, Phosphorus, Magnesium, Vitamin D, and Fluoride. Standing Committee on the Scientific Evaluation of Dietary Reference Intakes, Food and Nutrition Board, Institute of Medicine. Washington, DC: National Academy Press.

Hanes DA, Weaver CM, Heaney RP \& Wastney ME (1999a) Absorption of calcium oxalate does not require dissociation in rats. Journal of Nutrition 129, 170-173.

Hanes DA, Weaver CM \& Wastney ME (1999b) Calcium and oxalic acid kinetics are different in rats. Journal of Nutrition 129, $165-169$.

Hargreaves T \& Rose GA (1965) The reproducibility of the balance method in man as applied to calcium and phosphorus. Clinical Science 28, 537-542

Heaney RP, Dowell S, Bierman J, Hale C \& Bendich A (2001) Absorbability and cost effectiveness in calcium supplementation. Journal of the American College of Nutrition 20 , 239-246.

Heaney RP, Recker RR \& Hinders SM (1988) Variability of calcium absorption. American Journal of Clinical Nutrition 47, 262-264.

Heaney RP, Recker RR \& Weaver CM (1990a) Absorbability of calcium sources. The limited role of solubility. Calcified Tissue International 46, 300-304.

Heaney RP, Saito Y \& Orimo H (1994) Effect of caseinphosphopeptide on absorbability of co-ingested calcium in normal postmenopausal women. Journal of Bone and Mineral Metabolism 12, 77-81.

Heaney RP \& Weaver CM (1989) Oxalate: effect on calcium absorbability. American Journal of Clinical Nutrition 50, $830-832$.

Heaney RP \& Weaver CM (1995) Effect of psyllium on absorption of co-ingested calcium. Journal of American Geriatric Society 43, 1-3.

Heaney RP, Weaver CM \& Fitzsimmsons ML (1990b) The influence of calcium load on absorption fraction. American Journal of Clinical Nutrition 5, 1135-1138.

Heaney RP, Weaver CM \& Fitzsimmons ML (1991) Soybean phytate content: effect on calcium absorption. American Journal of Clinical Nutrition 53, 745-747.

Heller JH (1999) The role of calcium in the prevention of kidney stones. Journal of American College of Nutrition $\mathbf{1 8}$, 373S-378S

Holt PR (1999) Dairy foods and prevention of colon cancer: human studies. Journal of the American College of Nutrition 18, 379S-391S.

Jackman LA, Millane SS, Martin BR, Wood OB, McCabe GP, Peacock M \& Weaver CM (1997) Calcium retention in relation to calcium intake and postmenarcheal age in adolescent females. American Journal of Clinical Nutrition 66, 327-333.

Kelsay JL \& Prather ES (1983) Mineral balances of human subjects consuming spinach in a low-fiber diet and in a diet containing fruits and vegetables. American Journal of Clinical Nutrition 38, 12-19.

Koo J, Weaver CM, Neylan MJ \& Miller GD (1993) Isotopic tracer techniques for assessing calcium absorption in rats. Journal of Nutritional Biochemistry 4, 72-76.

Liebman M \& Doane L (1989) Calcium and zinc balances during consumption of high and low oxalate-containing vegetables. Nutrition Research 9, 947-955.

Liebman M \& Landis W (1989) Calcium and zinc balances of premenopausal women consuming tofu- compared to cheesecontaining diets. Nutrition Research 9, 5-14.

Lin Y-C, Lyle RM, McCabe LD, McCabe GP, Weaver CM \& Teegarden D (2000) Calcium intake relates to change in body weight in young women. Journal of the American College of Nutrition 19, 754-760.

Lipkin M \& Newmark HL (1999) Vitamin D, calcium and prevention of breast cancer: a review. Journal of the American College of Nutrition 18, 392S-397S.

McCance RA \& Widdowson EM (1942) Mineral metabolism of healthy adults on white and brown bread dietaries. Journal of Physiology 101, 44-85.

McCarron DA \& Reusser ME (1999) Finding consensus in the dietary calcium-blood pressure debate. Journal of the American College of Nutrition 18, 398S-405S.

Matkovic V \& Heaney RP (1992) Calcium balance during human growth: evidence for threshold behavior. American Journal of Clinical Nutrition 55, 992-996.

Mertz W (1987) Use and misuse of balance studies. Journal of Nutrition 117, 1811-1813.

Miller JZ, Smith DL, Flora L, Slemenda C, Juang X \& Johnston CC (1988) Calcium absorption from calcium carbonate and a new form of calcium (CCM) in healthy male and female adolescents. American Journal of Clinical Nutrition 48, $1291-1294$.

Morris ER \& Ellis R (1985) Bioavailability of dietary calcium: effect of phytate on adult men consuming nonvegetarian diets. In Nutritional Bioavailability of Calcium, pp. 63-72 [C Kies, editor]. Washington, DC: American Chemical Society.

O'Brien KO, Abrams SA, Liang LK, Ellis KJ \& Gagel RF (1998) Bone turnover response to changes in calcium intake is altered in girls and adult women in families with histories of osteoporosis. Journal of Bone and Mineral Research 13, 491-499.

Pansu D, Bellaton C, Roche C \& Bronner F (1983) Duodenal and ileal calcium absorption in the rat and effects of vitamin D. American Journal of Physiology 244, G695-G700.

Pappenheimer JR \& Reiss KZ (1987) Contribution of solvent drag through intracellular to absorption of nutrients by the small 
intestine of the rat. Journal of Membrane Biology 100, $123-136$.

Pinto M, Robine-Leon S, Appay M, Kedinger M, Triadou N, Dussaulx E, Lacroix B, Simon-Assmann P, Haffen K, Fogh J \& Zweibaum A (1983) Enterocyte-like differentiation and polarization of the human colon carcinoma cell line Caco-2 in culture. Biology of the Cell 47, 323-330.

Schanler R \& Abrams SA (1995) Postnatal attainment of intrauterine mineral accretion rates in low birth weight infants fed fortified human milk. Journal of Pediatrics 126, $441-447$.

Shen X, Weaver CM, Kempa-Steczko A, Martin BR, Phillippy BQ \& Heaney RP (1998) An inositol phosphate as a calcium absorption enhancer in rats. Journal of Nutritional Biochemistry 9, 298-301.

Thys-Jacobs S, Starkey P, Bernstein D \& Tian J (1998) Premenstrual Syndrome Study Group. Calcium carbonate and premenstrual syndrome: effects on premenstrual and menstrual symptoms. American Journal of Obstetrics and Gynecology 179, 444-452.

Tsugawa N, Yamabe T, Takeuchi A, Kamao M, Nakagawa K, Nishijima K \& Okano T (1999) Intestinal absorption of calcium from calcium ascorbate in rats. Journal of Bone and Mineral Metabolism 17, 30-36.

van den Heuvel E, Muys T, van Dokskum W \& Schaafsma G (1999) Oligofructose stimulates calcium absorption in adolescents. American Journal of Clinical Nutrition 69, $544-548$.

Wastney ME, Martin BR, Peacock M, Smith D, Jiang X-Y, Jackman LA \& Weaver CM (2000) Changes in calcium kinetics in adolescent girls induced by high calcium intake. Journal of Clinical Endocrinology and Metabolism 85, 4470-4475.

Wastney ME, Ng J, Smith D, Martin BR, Peacock M \& Weaver CM (1996) Differences in calcium kinetics between adolescent girls and young women. American Journal of Physiology 271, R208-R216.

Weaver CM (1998) Use of calcium tracers and biomarkers to determine calcium kinetics and bone turnover. Bone 22, 103S-104S.

Weaver CM, Heaney RP, Martin BR \& Fitzsimmons ML (1991) Human calcium absorption from whole wheat products. Journal of Nutrition 121, 1769-1775.

Weaver CM, Heaney RP, Teegarden D \& Hinders SM (1996) Wheat bran abolishes the inverse relationship between calcium load size and absorption fraction in women. Journal of Nutrition 126, 303-307.

Weaver CM, Proulx WR \& Heaney RP (1999) Choices for achieving dietary calcium within a vegetarian diet. American Journal of Clinical Nutrition 70, 543S-548S.

Weaver CM, Spence LA \& Lipscomb ER (2001) Phytoestrogens and bone health. In Nutritional Aspects of Osteoporosis, pp. 315-324 [P Burckhardt, B Dawson-Hughes and RP Heaney, editors]. New York: Academic Press.

Yee S (1997) In vitro permeability across Caco-2 cells (colonic) can predict in vivo (small intestinal) absorption in man fact or myth. Pharmaceutical Research 14, 763-766.

Zemel MB, Shi H, Greer B, Direnzo D \& Zemel PC (2000) Regulation of adiposity by dietary calcium. FASEB Journal 14, $1132-1138$. 